\title{
DO INDONESIAN MANAGERS TIME THEIR CORPORATE BONDS?
}

\author{
Christine Andreani ${ }^{1}$ \\ BINUS University International \\ Dewi Tamara ${ }^{2}$ \\ BINUS Business School, BINUS University
}

\begin{abstract}
Corporate bonds are becoming popular in Indonesian capital market due to the ongoing decline in interest rates and the increase in credit rating. Debt Market Timing Theory argues that managers try to time their bonds issuance according to the market interest rate, relatively. This paper aims to analyze the debt issuance timing profile of Indonesian public listed companies. The samples are 24 bonds issuances, which have maturity period between 3 to 7, and companies already issued more than 1 bond issued within year 2009 and 2011 . The manager's behavior to time government bond rates is observed in the 5 working days window, whether the corporate bonds being issued at the lowest market interest rate (i.e., government bond rates) on the window. Bootstrap method is utilized to construct counterfactual data. The research finds that 7 out of 24 bonds issuance were issued at the lowest government bond yield within the window. Indonesian public listed companies had no ability to time their bond issuances during period 2009 until 2011. This paper reveals that the frequency of bond issuances made by each Indonesian company does not necessarily determine their capability to time government bond rates. However, bootstrap is a useful and more robust tool to help assessing the debt market timing ability when the samples taken are small in numbers.
\end{abstract}

Keywords: corporate bond, bond market timing.

\footnotetext{
${ }^{1}$ Graduated from School of Accounting (Christine_ithien@yahoo.com)

${ }^{2}$ Faculty of Business, School of Accounting and Finance

(tamara_dewi@yahoo.com)
} 


\section{INTRODUCTION}

\section{Background}

Corporate bond has grown rapidly in Indonesian capital market since the beginning of 2003 (Asian Development Bank (ADB) Team, 2012). Although corporate bonds are listed in Indonesian Stock Exchange, all transactions are traded Over the Counter (Asian Development Bank (ADB) Team, 2012). In the first two months of 2012, 6.75 trillion rupiah has been raised in the bond market compared to only 2.32 trillion rupiah in share Initial Public Offerings (IPOs) and right issues in the stock market (Indonomics, 2012). The reason behind this popularity are the ongoing decline of Indonesian interest rates in recent years and the bonds rating that has been upgraded to investment grade credit rating by Fitch Rating Agency in 2012 (Bloomberg, 2012). This fact has provided an idea that many large Indonesian companies are nowadays prefer debt to stock financing due to the great bond market condition in Indonesia.

Indonesian companies that are willing to issue bonds must conform to Bapepam-LK (Badan Pengawas Pasar Modal dan Lembaga Keuangan) and Indonesian Stock Exchange regulations. Before doing public offering of corporate bonds, the companies must go through some standardized and timely processes regulated by Bapepam-LK. There are 290 outstanding corporate bonds in Indonesian Stock Exchange in February 2013. All these corporate bonds are those that were issued through Exchange Traded.

Market Timing Theory is a theory that links management's financing decision to the capital market situation. Management is believed to do equity financing when the company has high Market to Book Ratio (its share price is overvalued), whereas switching to debt financing if the cost of debt is relatively low (Baker \& Wurgler, 2002). This theory has emerged recently as a new promising concept to determine the right financing decision.

Market Timing Theory is commonly observed on equity financing rather than on debt financing by many researchers. In Frank and Nezafat research (2010), it was stated that Boney, Comer \& Kelly (2005) expressed their concern on the non-existence of research that examines Debt Market Timing despite the fact that market timing is a 
major investment strategy employed more often by bond fund managers compared to stock fund managers. The research of Frank and Nezafat was considered as a pioneer for investigations on debt market timing.

In this paper, the author is going to examine whether corporate bond managers has the ability to time bond issuance that generates the most profitable financing method. Graham and Harvey (2001) found that interest rate is the most determinant aspect in making debt policy decision. The managers will be most likely to issue bonds on dates that the interest rates are deemed to be remarkably low. On such condition, the issuer is in advantageous situation with low interest payment along the bond's maturity.

To investigate the sample's ability to time the bond issuances, the author is going to formulate a feasible alternative bond issuing decisions (counterfactuals) in a one-week ( 5 working days) window within the actual issuance date. In other words, the author observes not only the government bond rate in corporate bond issuance date, but also the government bond rates 2 days before and 2 days after the actual issuing date $(\mathrm{r}-2, \mathrm{r}-1, \mathrm{r}, \mathrm{r}+1, \mathrm{r}+2)$. To construct standard error, the author utilized Bootstrapping method by re-sampling the data 1000 times for each window. The application of time window within actual issuance date and the construction of bootstrap data has already been applied by Frank and Nezafat (2010) to test Debt Market Timing in The United States context.

The best date to issue bonds will be depicted by the date that has the lowest cost of debt within the time windows. However, in this paper the ability of managers to issue bonds at the right timing will be analyzed not by simply comparing the government bond rate at $t$ (on the corporate bond actual issuance date) to the window, but by comparing it to the bootstrapped window (1000 data each working days). If managements have perfect ability to do debt market timing, within the bootstrap time window they will be more likely to issue bonds on the date that has the lowest interest rate $\left(r_{\min }\right)$. If they do not have debt market timing ability, they issued bonds at the average cost $\left(r_{\text {mean }}\right)$. On the other side, if they have the worst ability to time debt financing, they issue at the date on which the cost is high $\left(\mathrm{r}_{\max }\right)$. One Sample T-Test is going to be implemented to check whether the mean 
of actual window and bootstrap window is statistically different from each other.

\section{LITERATURE REVIEW}

\section{Bond Market Timing}

Baker and Wurgler (2002) proposed a modern theory of capital structure known as Market Timing Theory. This theory acknowledged capital structure as the cumulative outcome of past attempts to time the market (Baker \& Wurgler, 2002). This theory is in line with Modigliani \& Miller and Pecking Order theories that do not put effort in maintaining optimal capital structure. They believed that the focus of financing decision is not in maintaining the optimal capital structure but in timing the appropriate and beneficial financing decision.

According to Market Timing theory, managers should determine the appropriate financing decision in the best timing that would generates as much benefits as possible to the company. Managers ought to time the capital issuance that has relatively low cost without regard to the capital structure. They should issue equity when the share prices are overvalued while switch to issue debt when the cost of debt is low. Many evidences reveal that market timing is an important aspect of real financing decision.

As market timing theory is about issuing capital at the right time that enables the company to raise money in a cheaply manner, bond market timing refers to the practice of issuing bond when the interest rate is low. In such condition, the bond issuers gain two benefits in one time. They do not only subject to cheap coupon payment along the bond maturity, but also being able to sell the bond at high market value (overvaluation of bond price). This can be understood by looking at the inverse correlation between interest rate and bond price (Bodie, Kane and Marcus, 2011, p. 475):

$$
P=C \times \frac{1}{r}\left[1-\frac{1}{\left(1+r^{r}\right)^{r}}\right]+F^{r} \times \frac{1}{(1+r)^{r}}
$$

Where:

$\mathrm{P}=$ Bond Market Price

$\mathrm{C}=$ Coupon interest payment based on contractual interest rate 
$\mathrm{I}=$ Market interest rate

$\mathrm{N}=$ Number of payments

$\mathrm{F}=$ Face value of the bonds at the end of maturity

Antoniou, Zhao, and Zhou (2009) found that CFOs do indeed try to time the debt issuance by observing the condition of credit market at that relevant time (Frank \& Nezafat, 2010). This evidence supports the finding of survey undertaken by Graham and Harvey (2001) that CFOs consider interest rate as the most influencing factors in the pursue of issuing bonds. They are willing to issue bonds at the time the cost of debt (interest rate) is relatively low.

Interest rate in the market is the most influential benchmark to the coupon rate determination of corporate bonds. Since coupon rate determines the regular payment that will be made by the bond issuer throughout the life of the bonds until its maturity date, it is the cost of companies seeking funds through bond issuance. Low government bond rate will eventually enable the companies to issue bond at a low cost.

Some literatures of debt market timing investigated the ability of managers in timing the bond issuance with regards to the selection of appropriate bond maturity. Graham and Harvey (2001) found that market timing is the third most crucial determinant of the choices of long term or short term debt.

Based on the literatures, debt issuance relies heavily on the past and future interest rate. Forward looking timing is the practice of measuring the appropriate debt maturity by relying on managers' interest rate forecasting ability. The finding from Graham and Harvey (2001) supports forward looking timing. They believe that managers will be likely to issue short term bond either when they believe that short term interest rate is low compared to long term interest rate or when they believe the interest rates is going to decline in the future. This hypothesis is supported by other researchers, such as Bancel and Mittoo (2004), Baker, Greenwood, and Wurgler (2002), Henderson, Jegadeesh, and Weisbach (2006) who found that managers issue bonds at the time they believed that the future interest rates is going to increase (forward looking timing) (Comer et al., 2012). At such prediction, managers try to time the debt issuance by issuing long 
term debt prior the increase of interest rate in order to gain benefits from the predicted situation.

Another argument of forward looking timing is presented by Taggart (1985). He correlates forecasted inflation, tax deduction and debt financing to understand the consideration of managers that issuing bonds. He argues that at the time the managers are certain that there will be inflation in the future; they will be likely to issue bonds to avoid higher cost of debt in the future. The rationality behind this negative correlation between inflation and interest rate is explained by the monetary policy imposed by government. In macroeconomic study, this policy is intended to keep the economy in balance. Government will tighten the interest rate (increase the interest rate) to avert inflation and lease interest rate (lowering the interest rate) to spur inflation.

Contradict to forward looking timing, Barry, Mann, Mihov, and Rodriguez (2005) argue that managers cannot successfully time future interest rates (Frank \& Nezafat, 2010). Thus, managers' guidance in making debt financing is by looking at past interest rates (backward looking). It is considered as good time to issue debt when the current interest rate is low compared to the historical rate.

On the other side, Barry et al. (2009) is the first who observed the influence of interest rate fluctuations to the determination of issuing whether floating or fixed rate debt. Unlike previous researches that seek to explore debt market timing by observing financial factors affecting leverage, Boney, Comer and Kelly (2005), Frank and Nezafat (2010), Bougatef and Chichti (2011), and Barry et al. (2009) investigated whether managers had successfully time their debt issuance.

Boney et al. (2005) investigated whether Morningstar Principia Pro CD's high quality bond mutual funds during 1994-2003 engaged in market timing between cash and bond and across maturities. Besides, they also examine the market timing skills of the samples. The results show that bond mutual funds do engage in market timing but they have perverse market timing ability between bonds and cash and also across bonds maturity. 
Contradict to Barry et al. (2009) that found no evidence of managers' capabilities in timing bonds issuance, Bougatef and Chichti (2011) found that French and Tunisian firms' managers did issue bonds in time of low interest rate. However, while Tunisian firms' were able to predict increase of interest rate and hence issue bonds before interest rate increases, French firms failed to do so.

Frank and Nezafat (2010) examined US companies' ability to time the bond issuance by using bootstrapping method. They compare US corporate bond actual issuance date with the date that is considered as the best date to issue bond in the formulated counterfactual set. The counterfactual set is the 5-working days window made within the actual bond issuing date. Companies with perfect debt market timing ability are expected to issue bond at the date with the lowest interest rate within the windows. The result discovered no market timing ability of corporate's bond issuance a over one week and one month window, but attain some borderline evidence over one quarter period (Frank \& Nezafat, 2010).

As debt market timing is less investigated compared to equity market timing, there is still much to be explored. Additionally, until this time, the authors do not find a research about debt market timing on Indonesian context. To fill the gap, this paper is going to perform an empirical study of Credit Market Timing that has previously been conducted by Frank and Nezafat (2010) on the United Stated firms. The research will be adjusted to Indonesian corporate bond situation and retested in Indonesian context.

The objective of this research focused on investigating the ability of Indonesian public listed companies' managers to do bond market timing that gives the most beneficial return to the company. The researcher is going to use the same method as Frank and Nezafat's method (2010) that construct a counterfactual set through Bootstrapping. This method is applied to this research for the purpose of measuring its effectiveness and validity in testing managers' debt market timing ability in Indonesian context.

The summary of some literature reviews found and selected by the researcher are depicted in the following table: 
Table 1. Literature Reviews

\begin{tabular}{|c|c|}
\hline Year & Glimpse of Literature Reviews \\
\hline 2001 & $\begin{array}{l}\text { Graham and Harvey found that interest rate is the most } \\
\text { influencing factor affecting companies in issuing debt }\end{array}$ \\
\hline 2002 & $\begin{array}{l}\text { Baker \& Wurgler introduced Market Timing Theory. } \\
\text { The Right Financing Decision should be made according } \\
\text { to the market conditions. Market to Book Ratio is used } \\
\text { as the proxy of under and overvaluation that } \\
\text { consequently affect the financing decision. Market to } \\
\text { Book Ratio, PPE/Assets \& EBITDA/Asset are deemed } \\
\text { to be financial variables affecting leverage }\end{array}$ \\
\hline 2002 & $\begin{array}{l}\text { Baker, Greenwood, and Wurgler believed on forward } \\
\text { looking debt market timing: Managers issue bonds when } \\
\text { they believed future interest rate is going to increase }\end{array}$ \\
\hline 2005 & $\begin{array}{l}\text { Barry, Mann, Mihov, and Rodriguez argued that } \\
\text { managers cannot predict interest rate. Thus should look } \\
\text { at past interest rate to determine the right time to issue } \\
\text { debt (backward looking market timing) }\end{array}$ \\
\hline 2005 & $\begin{array}{l}\text { Hovakimian adds variables that affect leverage: size, } \\
\text { tangibility and profitability }\end{array}$ \\
\hline 2005 & $\begin{array}{l}\text { Leary and Robert used more robust model, GLS, } \\
\text { compared to Baker \& Wurgler's OLS model }\end{array}$ \\
\hline 2005 & $\begin{array}{l}\text { Boney, Comer and Kelly were the first to investigate the } \\
\text { debt market timing ability of high quality bond funds } \\
\text { between bond and cash, and also across bond maturity }\end{array}$ \\
\hline 2009 & $\begin{array}{l}\text { Antoniou, Zhao, and Zhou found that CFOs try to time } \\
\text { their debt issuances relative to the interest rate }\end{array}$ \\
\hline 2009 & $\begin{array}{l}\text { Barry, Mann, Mihov, and Rodriguez observed the } \\
\text { influence of interest rate fluctuations to the floating or } \\
\text { fixed rate debt issuance decision }\end{array}$ \\
\hline 2011 & $\begin{array}{l}\text { Bougatef and Chichti investigated debt market timing } \\
\text { ability of Tunisian \& French firms. Its finding shows } \\
\text { that Tunisian firms' are able to predict increase of } \\
\text { interest rate and hence issue bonds before the raise, } \\
\text { while French firms fail to do so. (Support Forward } \\
\text { Looking Market Timing) }\end{array}$ \\
\hline 2011 & $\begin{array}{l}\text { Frank and Nezafat examined US companies' ability to } \\
\text { do credit market timing in attempts to do debt market }\end{array}$ \\
\hline
\end{tabular}




\begin{tabular}{|c|l|}
\hline Year & \multicolumn{1}{c|}{ Glimpse of Literature Reviews } \\
\hline 2012 & $\begin{array}{l}\text { timing. They used bootstrapp and time series analysis. } \\
\text { The capabilities are analyzed in a week, month, and } \\
\text { quarter window } \\
\text { Setyawan \& Frensidy investigated the correlation } \\
\text { between leverage with M/B Ratio, PPE, after tax income } \\
\text { and total assets in Indonesian IPO firms }\end{array}$ \\
\hline
\end{tabular}

\section{Corporate Bonds in Indonesia}

There are two types of bonds in Indonesia, government bonds and corporate bonds. Bonds issued by The Government of Republic Indonesia are called government bonds, while corporate bonds refer to the bonds issued by either stated-owned entities (BUMN or Badan Umum Milik Negara) or private companies. In Indonesia, government bonds are in the form of Treasury Bond (T-Bond) \& SUKUK (Surat Berharga Syariah Negara) or Treasury Bills (Surat Perbendaharaan Negara or SPN), Islamic Treasury Bill (Surat Perbendaharaan NegaraSyariah), SBI (Sertifikat Bank Indonesia), Commercial Paper and Repurchase Agreement (Asian Development Bank (ADB) Team, 2012).

Government bond differs from corporate bond in terms of liquidity, rate offered and also trading volume. Government bond is more liquid compare to corporate bond. Indonesian government bonds were traded more, but offer relatively less rate than corporate bonds (Tanaga, 2008).

Private companies ordinarily issue bonds for financing their expansion or to meet its short or long term financial needs. Investors' financial power to pay a large sum of the bond price enables the managers to attain large sum of money in a relatively fast period.

Actually, private companies can do debt financing by either borrowing money from banks or issuing debt securities. But, the prospects and benefits offered by issuing debt securities such as bond are much more promising than take loans from banks.

As an intermediary, banks pool fund from investors in the form of time deposits and allocate the funds to give loans to the companies who need funds. Spread is the benefit a bank gets as a consequence of 
the difference between rate charged to those need funds and rate offered to depositors. Assume that in Indonesia, bank offers 5\% interest on average to the depositors and charged $12 \%$ loan rate to the corporate borrowers in 2012. In this case, bank gets $7 \%$ spread benefit. The procedure is plotted in the below diagram:

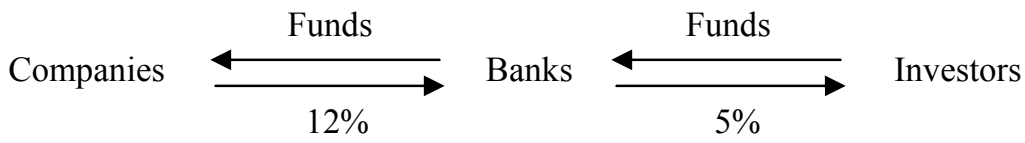

Figure 1. The Procedure of Bank Loan and Bank Deposit

When a company issues debt securities such as bonds (generally known as corporate bonds), the company make a debt agreement directly to the investors. Since the mechanism does not involve intermediary, both bond issuer and investors can deal in a profitable lower rate. Assume in Indonesia, corporate bonds offer $10 \%$ coupon on average. It allows company to borrow money at lower cost of debt than $12 \%$ bank loans. On the other hand investors also get higher payback interest rate than $5 \%$ deposit rate offered by banks (Indonomics, 2012). The mechanism of corporate bonds is plotted in the below diagram:

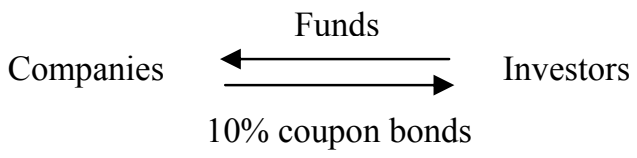

Figure 2. The Procedure of Corporate Bonds

From the investors benefit perspective, corporate bonds are indeed more profitable compared to bank deposit but also enforce them to face greater risk. At time the bond's issuer cannot pay the debt in the future, the investors should acquiesce their money. Unlike such case, investors in Indonesia that put their money into the Indonesian bank deposit will be guaranteed by Lembaga Penjamin Simpanan (LPS).

Lembaga Penjamin Simpanan (LPS) insured depositors that has money under 2 billion rupiahs in their bank deposit accounts. Accordingly, if the banks cannot meet its obligation to pay back 
depositors funds, LPS will still pay back the depositors' money (but only for those whose deposit is under 2 billion rupiahs). Although bank deposits offer low rate, the depositors face lower risk due to the guarantee of not losing their money under certain amount.

With the disclosed benefits and risks, the investors' choice depends on their characteristics, whether they are risk loving or risk averse persons. Risk lovers will be more likely to buy corporate bonds, while risk averse investors will stay at a safe but low interest income from bank deposit.

\section{Corporate Bond Issuance in Indonesia}

Businesses are commonly raise capital through the selling of securities such as stocks, bonds, notes, debentures, etc. The process of issuing these securities is called an offering. There are two kinds of offering, private and public. Since September 2006, all bond transactions in Indonesia, both Exchange Traded and Over The Counter Transactions, are obliged to be reported to Bapepam-LK (Badan Pengawas Pasar Modal dan Lembaga Keuangan) through stock exchange system no more than 1 hour after the transactions.

A private offering does not oblige the securities' issuers to file a registration statement with the state and federal government. This offering is commonly known as Exchange Traded Funds (ETF). The issuer offers the securities to limited persons who are well informed about the issuer company.

Unlike private offering, public offering requires much more complicated procedure before it can officially issue the securities to the public. In Indonesia, companies that have intention to do public offering of bonds are subject to regulations made by Bapepam-LK and Indonesian Stock Exchange.

Intermediaries in Indonesian corporate bond issuance are securities companies approved by Bapepam-LK that may act as investment manager, broker dealer or underwriters. An investment manager gives advice regarding the prospective investments. A broker dealer acts as both a broker (agent) that helps handling transactions that are placed on behalf of the client and also as a dealer (principal) that initiates transactions for its brokerage firm. An underwriter is a securities 
dealer that helps the bond issuer to sell the bonds. The mechanism is that the underwriter buy bonds from the issuer and resell it to the investors in a higher price. Custodian in Indonesian corporate bond issuance is KPEI (Kliring Penjaminan Efek Indonesia) for Exchange Traded transactions and KSEI (PT Kustodian Sentral Efek Indonesia) for Over the Counter transactions, who provides clearing and settlement services of the bond issuance.

To be eligible, Indonesian corporate bonds must obtain rating from Credit Rating Agency (CRA) listed by Bapepam-LK before allowed to do public offering. The rating is about CRA's opinion on the ability of the bond issuer to meet its obligation in a timely manner (company rating) and the rating of the debt that is going to be issued (instrument rating). Three listed CRA by Bapepam-LK are PT Fitch Ratings Indonesia, PT Pemeringkat Efek Indonesia (PEFINDO), and PT ICRA Indonesia.

\section{Research hypothesis development}

Market Timing theory correlates the companies' financing decision to the market condition. Henceforth, the debt market timing theory points out that the debt financing decision will be made if there is a favorable market condition to do that kind of financing compared to stock financing.

As stated earlier, Graham and Harvey (2001), and Antoniou et al. (2009) found that the CFOs do try to time their bond issuance by issuing bonds when the interest rate in that relevant time is relatively low. This finding indicates that in the effort of doing debt financing decision, companies take into account the favorable market condition that enables them to obtain money in a relatively low cost.

Since the cost of seeking fund through issuing corporate bonds is the coupon rate agreed on the bonds, there is a necessity to understand factors influencing it. The coupon rate of corporate bond is influenced by the government bond rate (risk free rate) in the market and the markup.

The markup is affected by both the companies' and bonds' volatility, the length of bonds maturity, etc. If only the Credit Default Swap (CDS) price is available per company basis in Indonesia, the markup 
can also be analyzed to determine the ability of companies to do debt market timing in time that the CDS price is low. The low CDS price indicates that investors can trust the companies and hence companies are able to issue bond at a relatively low coupon rate. However, since Indonesia has not such advanced information regarding CDS price, the markup is assumed to be fixed in this paper. Consequently, government bond rate is the sole variable that will be analyzed in this research.

Surat Utang Negara (SUN) is set by the researcher as the most proper government bond proxy whose rate will be very likely to influence the determination of coupon rate in Indonesian corporate bonds. This type of obligation is chosen rather than SBI (Sertifikat Bank Indonesia) due to its maturity compatibility with Indonesian corporate bonds that generally have long maturity, more than 1 year. The escalation of Surat Utang Negara (SUN) rate will in effect causes an increase in corporate bonds coupon rate.

To prove the theory found by Graham and Harvey (2001), and Antoniou et al. (2009) on Indonesian corporate bond issuances, we hypothesize that Indonesian public listed companies have the ability to time the rate of Surat Utang Negara (SUN)

\section{RESEARCH DESIGN}

\section{Data}

The data used in this study is the daily yield of Indonesian government bonds corresponds to the corporate bonds issuance date within year 2009 until 2011 time period. The government bond yields will be observed on a 1 week (5-working days) window that is centered on the actual corporate bond issuance date.

The samples of the study are the 3-year and 7-year maturity corporate bonds being issued during 2009 until 2011, by which the company issued more than 1 bond of these kinds of maturities. The researcher chooses the 3 year maturity bonds as the representative of bonds with maturity less than 5 years that have bonds issuances at most, and 7 year maturity bonds as the representative of bonds between 5 years maturity and 10 years maturity with the most frequently bond 
issuance during 2009-2011. The authors take only companies issued more than 1 bond of 3-year and 7-year maturity because these companies are deemed to have more capability to do debt market timing.

The bonds selected as samples are limited to fixed rate, not floating rate corporate bonds whose types are not subordinate bonds, not SUKUK, and not Syariah bonds. The author uses the fixed rate bonds because this kind of bonds requires the issuer to pay regular amount of money based on the specified coupon bond rates. This regular payment based on the specified coupon bond rates was affected directly by the government bond yield at that specified corporate bond issuance date. Hence after, the debt market timing for these bonds is crucial.

Subordinate bonds, SUKUK and Syariah bond are excluded because these kind of bonds are the zero coupon bonds. Zero coupon bonds do not require regular payments from the issuer to the investor. Henceforth, there will be no coupon rates influenced by the government bond yield at the corporate bond issuance date that represents the cost of bond issuer to do issuance. There is no need to time these kinds of corporate bonds issuances.

The data is collected from Indonesian Stock Exchange website and IBPA website. Given that the samples are selected purposely based on the limitations set by the researcher, this study is categorized as purposive sampling. ${ }^{3}$

There will be only one proxy to be used in this study as a measurement that affects company's decision on determining the best time to issue bonds. That is the risk free rate. In this study, the daily rate of Surat Utang Negara (SUN) benchmark rate is set as the proxy of risk free rate that will affect corporate bond coupon rates. This rate is regarded as the only element that affects company's decision on the best date to issue bond. Daily SUN rates on 5-working days within companies bond issuing date will be analyzed

\footnotetext{
${ }^{3}$ Purposive sampling is a way to select units from the population based on specific purposes in order to answer the research question.
} 
The researcher begins the data collection by sorting the corporate bonds outstanding until February 2013 in the Indonesian Stock Exchange website (www.idx.co.id) without taking into account subordinate corporate bonds, Syariah corporate bonds, and SUKUK. The related details of each selected corporate bonds (the issuer, the coupon rate, date issued, nominal amount, maturity years) were extracted to Microsoft Excel Worksheet by searching on Yahoo! Finance website.

Afterwards, the author sort the data by its issuance date and taking into account only corporate bonds issued in the 2009 until 2011 time periods to be eligible for the next sample limitation. However, the data are then limited to the 3-year maturity and 7-year maturity bond issuances.

The data are then classified according to its issuer and the researcher listed how many bonds of these 2 maturities bonds were issued by each company. The next step, the author selects only representative companies that issued more than 1 bond during 2009 - 2011. The samples are then 9 companies with total issuances of 24 bonds. For each corporate bond of these representative companies, the researcher made a time windows (one week or 5 working days) within the bonds issuance date in Microsoft Excel Worksheet.

The final data collection was done by extracting the daily benchmark rate of government bonds from year 2009 until 2011 from Bloomberg. From each bond issuance, the author constructs counterfactual data set in the 5 working days window within the actual corporate bond issuance date. The daily government bond rates are extracted in a oneweek or 5 working days window $(\mathrm{r}-2, \mathrm{r}-1, \mathrm{r}, \mathrm{r}+1, \mathrm{r}+2)$ within each corporate bond's issuance date $(\mathrm{t}-2, \mathrm{t}-1, \mathrm{t}, \mathrm{t}+1, \mathrm{t}+2)$. $\mathrm{T}$ represents the actual bond issuance date and $r$ represents the government bond yield with equal maturity year to the issued corporate bond.

\section{Decision Rules}

There are three conditions applied for the hypothesis testing. Once the first condition of null hypothesis is not rejected, there is no need to go beyond the next condition. However, if the first condition's null hypothesis is rejected, the second condition will be tested. If the 
second condition's null hypothesis is again rejected, thenceforth there is a need to test the third condition.
$\begin{array}{ll}\text { First Condition: } & \text { Ho: } r_{t} \text { actual }=r_{\min } \text { bootstrap } \\ & H 1: r_{t} \text { actual } \neq r_{\min } \text { bootstrap }\end{array}$
Second Condition: $\quad$ Ho: $r_{t}$ actual $=r_{\text {mean }}$ bootstrap
$\mathrm{H} 1: \mathrm{r}_{\mathrm{t}}$ actual $\neq \mathrm{r}_{\text {mean }}$ bootstrap
Third Condition: $\quad$ Ho: $r_{t}$ actual $=r_{\max }$ bootstrap
$\mathrm{H} 1: \mathrm{r}_{\mathrm{t}}$ actual $\neq \mathrm{r}_{\max }$ bootstrap

The null hypothesis for the first condition will not be rejected if government bond rate at corporate bonds' issuance date is the lowest within the 5 working days bootstrap window $\left(r_{t}=r_{m i n}\right)$. The acceptance of this first condition hypothesis indicates that the company has the perfect ability to time its bond issuance.

For the second condition, the null hypothesis is not rejected as the government bond rate at corporate bonds' issuance date is the mean within the 5 working days bootstrap window $\left(r_{t}=r_{\text {mean }}\right)$. Under this condition, the company will be considered as not having the debt market timing ability.

Lastly, the null hypothesis of the third condition is not rejected if the government bond rate at corporate bonds' issuance date is the highest within the 5 working days bootstrap window $\left(r_{t}=r_{\max }\right)$, and under this condition the company is believed to have worst ability at doing the debt market timing.

The conclusion is made under the assumption that every company will try its best to successfully issue the corporate bond at the lowest possible rate using their maximum ability and effort. Hence after, their success in timing the debt issuances will be directly seen as having the ability to do so.

Data Analysis Method

The analysis of data uses bootstrap method and One Sample T-Test.

\section{Bootstrapping Method}

Bootstrapping is the method for computing confidence intervals around just about any statistic one could possibly want to estimate 
even when no formula exist for calculating a standard error (Efron \& Robert, 1993).

Differ from sampling distribution that selects multiple samples from the population then re-estimating the statistics (the mean or regression coefficient) from each observation, bootstrapping consider the samples drawn from the population to be the population and resampling the data from it. Each bootstrap sample is drawn with replacement that has the same sample size as the original (Methods Consultant, n.d.).

To observe the debt market timing ability of Indonesian companies, the author of this research is going to make a counterfactual set (bootstrap) that re-sampling the actual sample in a 1 week ( 5 working days) window. The window is defined as the date within the actual corporate bond issuance date.

One week windows $(\mathrm{t}-2, \mathrm{t}-1, \mathrm{t}, \mathrm{t}+1, \mathrm{t}+2)$ represents 2 working days before, the day of, and 2 working days after the actual bond issuing date. In the window, the author will extract data of daily Indonesian government bond benchmark rate based on the date $(\mathrm{r}-2, \mathrm{r}-1, \mathrm{r}, \mathrm{r}+1$, $\mathrm{r}+2$ ). The government bond benchmark rates that are used are adjusted with the time to maturity of the corporate bonds issued.

From each window of each bond issuance, the author remake sample using uniform random number generator ${ }^{4}$ to construct the same sample size as the actual sample (Bootstrap). Hence after, from the 1 week window, there will be a new data set $\left(\mathrm{r}^{*}-2, \mathrm{r}^{*}-1, \mathrm{r}^{*}, \mathrm{r}^{*}+1, \mathrm{r}^{*}+2\right)$. This data set produces one bootstrap sample. For each window of each bond, the re-sampling will be done 1000 times up until 1000 bootstrap samples are obtained.

\section{Ordinary Moving Averages Smoothing}

Time series patterns can be described in two basic terms, trend and seasonality. Trend is the pattern that recurs in a systematic interval

\footnotetext{
${ }^{4}$ Uniform random number generator is generating numbers that occur in a sequence, under the conditions: the values are uniformly distributed over a specific interval, and it is impossible to predict future values based on past or present values.
} 
over time, while seasonality is a component that does not repeat within the time range. Since the pattern of long term time series may be obscured by the variation from year to year, smoothing is applied to produce a better overall impression of the pattern (Levine, Stephan, Krehbiel \& Berenson, 2008, p. 649).

This research does not use the time series analysis, but utilizes Ordinary Moving Averages Smoothing feature from Time Series Analysis to eliminate the variation of daily government bond rates from year 2009 to 2011 . This smoothing involves averaging the data to eliminate the nonsystematic components of individual components (StatSoft, n.d., para. 10).

The researcher first gathers data of how many 3 year and 7 year maturity bonds were issued by each Indonesian representative company within 2009 and 2011 time periods. Afterwards, the researcher averages the total actual government bond benchmark rate on each date of the window by the number of bonds being issued. This becomes the procedure of making the data analysis per company basis.

The average or smoothed window is further being bootstrapped using uniform random number generator to construct counterfactual data set. There will be 1000 bootstrap data from each 5 working days window. Each average rate will be treated as the possible rate that the companies could have achieved if they had no timing ability and were selecting their bond issuing dates by chance over each time window.

\section{One Sample T-Test}

T-test is the appropriate statistical tool to test the hypothesis when the population standard deviation is unknown and when the sample size is relatively small (Keller, 2005). One sample t-test is a statistical test used to specified confidence interval; the author will determine whether the t-value generated from the test falls outside the acceptance region (Levine et al., 1998). The $\mathrm{t}$ statistic formula: (McClave and Sincich, 2006, p. 390 \& 391)

$$
i=\frac{8-\mu \theta}{s / \sqrt{n}}
$$


Where:

$\bar{X}=$ sample mean

$\mu \mathrm{o}=$ null hypothesized value of the population mean

$\mathrm{s}=$ sample standard deviation

$\mathrm{n}=$ sample size

The author sets 95\% confidence level for this research paper and hence after the $\alpha$ is 0.05 . The critical value based on this level of significance and the data's degrees of freedom (sample size minus 1) can be known from t-distribution table. The rejection rule is defined as follows:

$$
\begin{aligned}
& \text { Reject H0 if } t \text { (calculated from formula) }<-t \text { (from the table) } \\
& \text { Reject H0 if } t \text { (calculated from formula) }>\mathrm{t} \text { (from the table) }
\end{aligned}
$$

In this study, One Sample T-Test is implemented to test companies' debt market timing ability only on the base of overall data. As the three conditions of hypothesis testing are aimed to compare the actual government bond yield at time $t\left(r_{t}\right)$ to either one of the 3 values $\left(r_{\min }\right.$, $r_{\text {mean }}$ or $r_{\text {max }}$ ) of the bootstrap government bond yield in the window, the t-test procedure for the first condition is as follow:

$$
t=\frac{r_{s}-r_{\min }}{s / \sqrt{n}}
$$

The null hypothesis of the first condition will be rejected if the $t$ resulted from the above formula is larger than the critical value presented by the t-distribution table. This rejection will further implied that the company's managers do not have the perfect ability to time debt market, or they failed to issue bonds at the lowest possible government bond rate within the 5 working days of the actual issuance date.

\section{RESULT AND DISCUSSION}

\section{Research sample}

The samples used in this research are limited to the 3-year maturity and 7-year maturity bonds being issued by representatives publicly listed companies in Indonesia during year 2009 - 2011.The study's 
representative companies are those issued 2 bonds, 3 bonds, 4 bonds and 5 bonds during the period.

The total for these representative companies are 9 out of 33 companies issued bond during 2009-2011. The other 24 companies issued only 1 bond during the three year period. The author examines only these representative companies because if there are companies having the ability to time the government bond benchmark rates, it should be these companies (who issued bonds more frequently than the others). The following tables summarized both companies' bond issuance activities during the period:

Table 2. Total Corporate Bonds Issued

\begin{tabular}{|c|c|c|c|c|c|c|}
\hline No & $\begin{array}{l}\text { Company } \\
\text { Name }\end{array}$ & $\begin{array}{c}\text { Code of } \\
\text { Company }\end{array}$ & Bond ID & $\begin{array}{l}\text { Date } \\
\text { Issued }\end{array}$ & $\begin{array}{l}\text { Maturity } \\
\text { Years }\end{array}$ & $\begin{array}{c}\text { Coupon } \\
\text { Rates }\end{array}$ \\
\hline \multirow{4}{*}{1} & \multirow{4}{*}{$\begin{array}{l}\text { PT Adira } \\
\text { Dinamika } \\
\text { Multi Finance }\end{array}$} & \multirow{4}{*}{$\mathrm{ADMF}$} & ADMF04C & $29 / 10 / 2010$ & 3 & 8.7 \\
\hline & & & ADMF04D & $29 / 10 / 2010$ & 3 & 9 \\
\hline & & & ADMF05C & $27 / 05 / 2011$ & 3 & 9.6 \\
\hline & & & ADMF01BCN1 & $16 / 12 / 2011$ & 3 & 8 \\
\hline \multirow{2}{*}{2} & \multirow{2}{*}{$\begin{array}{l}\text { PT Astra } \\
\text { Sedaya Finance }\end{array}$} & \multirow{2}{*}{ ASDF } & ASDF11D & $18 / 03 / 2010$ & 3 & 10.4 \\
\hline & & & ASDF12C & $25 / 02 / 2011$ & 3 & 9.7 \\
\hline \multirow{2}{*}{3} & \multirow{2}{*}{$\begin{array}{l}\text { PT BCA } \\
\text { Finance }\end{array}$} & \multirow{2}{*}{ BCAF } & BCAF03C & $23 / 03 / 2010$ & 3 & 10.45 \\
\hline & & & BCAF04D & $22 / 06 / 2011$ & 3 & 8.9 \\
\hline \multirow{5}{*}{4} & \multirow{5}{*}{$\begin{array}{l}\text { PT Bank } \\
\text { Ekspor } \\
\text { Indonesia }\end{array}$} & \multirow{5}{*}{ BEXI } & BEXI01ACN1 & $20 / 12 / 2011$ & 3 & 7 \\
\hline & & & BEXI01CCN1 & $20 / 12 / 2011$ & 7 & 8.5 \\
\hline & & & BEXI04D & $18 / 06 / 2009$ & 7 & 12.75 \\
\hline & & & BEXI05B & $08 / 07 / 2010$ & 3 & 8.85 \\
\hline & & & BEXI05D & $08 / 07 / 2010$ & 7 & 10 \\
\hline \multirow[b]{2}{*}{5} & \multirow{2}{*}{$\begin{array}{l}\text { PT Bank } \\
\text { Pembangunan } \\
\text { Daerah Jawa } \\
\text { Barat dan } \\
\text { Banten Tbk }\end{array}$} & \multirow[b]{2}{*}{ BJBR } & BJBR07A & $09 / 02 / 2011$ & 3 & 9.2 \\
\hline & & & BJBR07C & $09 / 02 / 2011$ & 7 & 10.4 \\
\hline \multirow[b]{2}{*}{6} & \multirow{2}{*}{$\begin{array}{l}\text { Bank } \\
\text { Pembangunan } \\
\text { Daerah Nusa } \\
\text { Tenggara } \\
\text { Timur }\end{array}$} & \multirow[b]{2}{*}{ BNTT } & BNTT01B & $08 / 07 / 2011$ & 3 & 9.9 \\
\hline & & & BNTT01D & 08/07/2011 & 7 & 11.5 \\
\hline \multirow{3}{*}{7} & \multirow{3}{*}{$\begin{array}{l}\text { PT Bank } \\
\text { Tabungan } \\
\text { Pensiunan } \\
\text { Nasional Tbk }\end{array}$} & \multirow{3}{*}{ BTPN } & BTPN01ACN1 & $28 / 06 / 2011$ & 3 & 9.25 \\
\hline & & & BTPN02A & $18 / 05 / 2010$ & 3 & 9.9 \\
\hline & & & BTPN03A & $22 / 12 / 2010$ & 3 & 8.75 \\
\hline \multirow[b]{2}{*}{8} & \multirow{2}{*}{$\begin{array}{l}\text { PT Federal } \\
\text { International } \\
\text { Finance }\end{array}$} & \multirow[b]{2}{*}{ FIFA } & FIFA10C & $29 / 04 / 2010$ & 3 & 10.15 \\
\hline & & & FIFA11C & $26 / 04 / 2011$ & 3 & 9.6 \\
\hline \multirow[b]{2}{*}{9} & \multirow{2}{*}{$\begin{array}{l}\text { PT Sarana } \\
\text { Multigriya } \\
\text { Finansial }\end{array}$} & \multirow[b]{2}{*}{ SMFP } & SMFP01CCN1 & $21 / 12 / 2011$ & 3 & 8.48 \\
\hline & & & SMFP03B & 08/07/2010 & 3 & 9.75 \\
\hline
\end{tabular}

Source: Indonesian Stock Exchange Website 
This research is aimed to analyze whether the representative Indonesian companies do have the ability to time their bond issuances by successfully issued bond at the lowest risk free rate within the oneweek window. Instead of just comparing the actual government bond rate in the actual 5 working days window, as an addition, the writer of this paper compare it to the bootstrapped window. Daily rates from each actual window is bootstrapped 1000 times using uniformly random number variable.

\section{Analysis of the Results}

In analyzing each company basis, it involves averaging the total actual government bond benchmark rates in the window to come up with one new window (using Ordinary Moving Averages Smoothing). This new window is bootstrapped 1000 times and the analysis with the same procedure will be done in this both actual and bootstrap window.

To analyze the whole bonds performance (total bonds issued basis), the authors utilize the One Sample T-Test. It involves averaging the total actual government bond benchmark rates only at time $t$ (actual corporate bond issuance date) and compares the value to the rate of government bond in the bootstrap windows of total bonds issued as a whole.

In conducting the One Sample t-test analysis for the overall bond performances, the amount entries to the 'test value' box will first the $r_{\min }$ from the total bootstrap window (represents the first condition). If the significance level of the test is less than 0.05 , the rejection of the first condition's null hypothesis will be made. Once the first condition is violated, the analysis will be continued to the second condition by inputting the $r_{\text {mean }}$ from the total bootstrap window in the 'test value' box of One Sample T-Test. The same procedure will be applied to determine the rejection of the condition.

If the second condition is again being rejected, last test using the third condition will be needed by inputting $r_{\max }$ from the total bootstrap window in the 'test value' box. However, if the outcome indicates that the first condition is not rejected (significance of the test is more than $0.05)$, there is no need to test the next condition. 
Individual Corporate Bonds' Market Timing Ability

The table below shows the actual 5 -working days window within the corporate bonds issuance date. The dates represents the dates on which the companies issued bond whereas the rates represents the government bond benchmark rates on that corresponding dates.

Table 3. Government Bond Rates on Actual 5-Days Window (in \%)

\begin{tabular}{|c|c|c|c|c|c|c|}
\hline Number & Bonds & T-2 & T-1 & $\mathbf{T}$ & $\mathbf{T}+\mathbf{1}$ & $T+2$ \\
\hline 1 & ADMF01BCN1 & 5,491 & 5,394 & 5,362 & 5,359 & 5,253 \\
\hline 2 & ADMF04C & 6,604 & 6,452 & 6,501 & 6,272 & 6,454 \\
\hline 3 & ADMF05C & 6,859 & 6,679 & 6,691 & 6,811 & 6,686 \\
\hline 4 & ADMF04D & 6,604 & 6,452 & 6,501 & 6,272 & 6,454 \\
\hline 5 & ASDF11D & 8,372 & 8,451 & 8,450 & 8,366 & 8,413 \\
\hline 6 & ASDF $12 \mathrm{C}$ & 8,301 & 8,256 & 8,255 & 8,282 & 8,295 \\
\hline 7 & BCAF03C & 8,366 & 8,413 & 8,451 & 8,365 & 8,410 \\
\hline 8 & BCAF04D & 6,739 & 6,889 & 6,799 & 6,799 & 6,759 \\
\hline 9 & BEXI01ACN1 & 5,362 & 5,359 & 5,253 & 5,279 & 5,253 \\
\hline 10 & BEXI01CCN1 & 6,153 & 6,166 & 6,042 & 6,081 & 6,028 \\
\hline 11 & BEXI04D & 11,450 & 11,500 & 11,750 & 11,750 & 11,5 \\
\hline 12 & BEXI05B & 7,883 & 7,704 & 7,751 & 7,617 & 7,664 \\
\hline 13 & BEXI05D & 8,267 & 8,197 & 8,201 & 8,160 & 8,194 \\
\hline 14 & BJBR07A & 8,351 & 8,106 & 8,308 & 8,306 & 8,373 \\
\hline 15 & BJBR07C & 8,553 & 8,667 & 8,774 & 8,924 & 8,954 \\
\hline 16 & BNTT01B & 6,684 & 6,431 & 6,497 & 6,675 & 6,508 \\
\hline 17 & BNTT01D & 7,332 & 7,160 & 7,317 & 7,158 & 7,157 \\
\hline 18 & BTPN01ACN1 & 6,759 & 6,714 & 6,655 & 6,655 & 6,705 \\
\hline 19 & BTPN02A & 8,498 & 8,701 & 8,594 & 8,678 & 8,629 \\
\hline 20 & BTPN03A & 7,055 & 6,954 & 6,894 & 7,048 & 6,998 \\
\hline 21 & FIFA01C & 8,068 & 8,401 & 8,331 & 8,277 & 8,159 \\
\hline 22 & FIFA11C & 6,877 & 6,953 & 7,119 & 7,072 & 7,041 \\
\hline 23 & SMFP01CCN1 & 5,359 & 5,253 & 5,279 & 5,253 & 5,265 \\
\hline 24 & SMFP03B & 7,883 & 7,704 & 7,751 & 7,617 & 7,664 \\
\hline
\end{tabular}

The analysis of debt market timing ability over each window in this research will be focused only on the rate of date $t$ from the actual window (column 4 of Table 4.2). Whereas, the value will be compared to the value of bootstrap window that are summarized by each descriptive statistics. 
Table 4. Descriptive Statistics for Each Bootstrap Window

\begin{tabular}{|l|r|r|r|r|}
\hline & ADMFO1BCN1 & ADMFO4C & ADMFO5C & \multicolumn{1}{|c|}{ ADMFO4D } \\
\hline Mean & 5,3706476 & 6,454415 & 6,7445406 & 6,455281 \\
\hline Standard Error & 0,001072233 & 0,001539968 & 0,001058698 & 0,001526064 \\
\hline Median & 5,362 & 6,454 & 6,691 & 6,454 \\
\hline Standard Deviation & 0,075818322 & 0,108892152 & 0,07486125 & 0,107909044 \\
\hline Minimum & 5,253 & 6,272 & 6,679 & 6,272 \\
\hline Maximum & 5,491 & 6,604 & 6,859 & 6,604 \\
\hline $\begin{array}{l}\text { Confidence Level } \\
(95,0 \%)\end{array}$ & 0,002102047 & 0,003019012 & 0,002075512 & 0,002991755 \\
\hline
\end{tabular}

At the time PT Adira Dinamika Multi Finance issued bond ADMF01BCN1, the 3-year maturity government bond benchmark rate is $5.362 \%$ (yield at $t$ on Table 4.2 ). Through comparison with the second column of Table 4, that rate is nearest to the mean value of the bootstrap 5-days window. The analysis for bond ADMF04C and ADMF04D is identical to ADMF01BCN1. Their government bond benchmark rate is closest to the mean of its 5-days window counterfactual data set (bootstrap). Based on this fact, the managers of PT Adira Dinamika Multi Finance are considered to have no debt market timing ability on determining the best date to issue these 3 bonds.

On the other hand, ADMF05C is outstanding by being issued at the date on which the 3-year maturiy government bond benchmark rate is closest to the minimum value of the bootstrap window. This means that the managers of PT Adira Dinamika Multi Finance had perfect ability in timing the issuance of Bond ADMF05C. 
Table 5. Descriptive Statistics for Each Bootstrap Window

\begin{tabular}{|l|r|r|}
\hline & \multicolumn{1}{|c|}{ ASDF11D } & \multicolumn{1}{c|}{ ASDF12C } \\
\hline Mean & 8,4107078 & 8,2779276 \\
\hline Standard Error & 0,000519527 & 0,000272804 \\
\hline Median & 8,413 & 8,282 \\
\hline Standard Deviation & 0,036736128 & 0,019290132 \\
\hline Minimum & 8,366 & 8,255 \\
\hline Maximum & 8,451 & 8,301 \\
\hline Confidence Level $(95,0 \%)$ & 0,001018501 & 0,000534815 \\
& & \\
\hline
\end{tabular}

Bond ASDF11D was being issued when the government bond yield was $8.450 \%$. This yield is the closest to the maximum value of bootstrap rates in the 5 working days. This condition indicates that managers had the worst ability to do debt market timing.

In contrast, the government bond rates at the issuance date of Bond ASDF12C (8.255\%) was exactly the minimum value of bootstrap window. Although PT Astra Sedaya Finance had the worst ability to time the issuance of Bond ASDF11D (issued at the maximum rates over the 5 working days bootstrap window), it had the perfect ability to time its ASDF12C issuance (issued at the minimum rates over the 5 working days bootstrap window).

Table 6. Descriptive Statistics for Each Bootstrap Window

\begin{tabular}{|l|l|l|}
\hline & BCAFO3C & BCAFO4D \\
\hline Mean & 8,4010952 & 6,797042 \\
\hline Standard Error & 0,000459494 & 0,000728757 \\
\hline Median & 8,41 & 6,799 \\
\hline Standard Deviation & 0,03249112 & 0,051530936 \\
\hline Minimum & 8,365 & 6,739 \\
\hline Maximum & 8,451 & 6,889 \\
\hline Confidence Level(95,0\%) & 0,000900809 & 0,001428684 \\
& & \\
\hline
\end{tabular}


In issuing Bond BCAF03C, the manager had the worst ability in timing the debt market. It is concluded as BCAF03C was issued exactly at the maximum government bond yield over the 5 working days bootstrap window shown at the above table $(8.451 \%)$. Whereas, government bond rates at the issuance date of BCAF04D was closest to the mean value of bootstrap window. On this bond issuance, PT BCA Finance is considered to have no debt market timing ability.

Table 7. Descriptive Statistics for Each Bootstrap Window

\begin{tabular}{|l|c|c|c|c|c|}
\hline & BEX101ACN1 & BEXIO1CCN1 & BEXIO4D & BEX105B & BEXIO5D \\
\hline Mean & 5,3011548 & 6,0938956 & 11,58895 & 7,7220514 & 8,2038124 \\
\hline $\begin{array}{l}\text { Standard } \\
\text { Error }\end{array}$ & 0,000695917 & 0,00079804 & 0,001866488 & 0,001261432 & 0,000488289 \\
\hline Median & 5,279 & 6,081 & 11,5 & 7,704 & 8,197 \\
\hline $\begin{array}{l}\text { Standard } \\
\text { Deviation }\end{array}$ & 0,049208763 & 0,056429967 & 0,131980609 & 0,089196681 & 0,034527219 \\
\hline Minimum & 5,253 & 6,028 & 11,45 & 7,617 & 8,16 \\
\hline Maximum & 5,362 & 6,166 & 11,75 & 7,883 & 8,267 \\
\hline $\begin{array}{l}\text { Confidence } \\
\text { Level(95,0\%) }\end{array}$ & 0,001364303 & 0.001564509 & 0,003659135 & 0,002472959 & 0,00095726 \\
\hline
\end{tabular}

At the time PT Bank Ekspor Indonesia issued BEXI01ACN1, the 3year maturity government bond benchmark rates on this date $(5.253 \%)$ is exactly the minimum rate in the 5-days windows of the bootstrap data. This means that PT Bank Ekspor Indonesia has perfect ability to time the issuance of BEXI01ACN1.

The outcome of second bond (BEXI01CCN1) is pretty much the same as bond BEXI01ACN1, since the government bond rate at the corporate bond issuance $(6.042 \%)$ is closest to the minimum value of bootstrap window (6.028\%). The managers of PT Bank Ekspor Indonesia did have the perfect ability to time government rates when it issued BEXI01CCN1.

As a contrast to the first and second bond of BEXI that were being issued at the date on which the government bond rate are the minimum of the bootstrap window (managers had the perfect market timing ability), BEXI04D was issued at the rate that represents exactly the the maximum value of its 5-days bootstrap window (11.75\%). 
This indicates that PT Bank Ekspor Indonesia had the worst ability to do debt market timing when it issued BEXI04D.

On the other hand, the outcome for bond BEXI05B and BEXI05D are much likely the same. The actual government bond benchmark rates in each corporate bond issuance date are closest to the mean value of each 5-days bootstrap window. This condition indicates that PT Bank Ekspor Indonesia did not have market timing ability at the time it issued BEXI05B and BEXI05D.

Table 8. Descriptive Statistics for Each Bootstrap Window

\begin{tabular}{|l|l|l|}
\hline & BJBRO7A & BJBRO7C \\
\hline Mean & 8,288092 & 8,7725346 \\
\hline Standard Error & 0,001355716 & 0,00214691 \\
\hline Median & 8,308 & 8,774 \\
\hline Standard Deviation & 0,095863567 & 0,151809432 \\
\hline Minimum & 8,106 & 8,553 \\
\hline Maximum & 8,373 & 8,954 \\
\hline Confidence Level(95,0\%) & 0,002657797 & 0,004208885 \\
\hline
\end{tabular}

For both bonds being issued by PT Bank Pembangunan Daerah Jawa Barat dan Banten Tbk (BJBR), the actual government bond yields on issuance dates are closest to its mean value of 5 working days bootstrap window. This means that the managers of this company had no market timing ability on all of its bond issuances during year 20092011.

Table 9. Descriptive Statistics for Each Bootstrap Window

\begin{tabular}{|l|l|l|}
\hline & BNTTO1B & BNTTO1D \\
\hline Mean & 6,5585188 & 7,224366 \\
\hline Standard Error & 0,001442554 & 0,001152947 \\
\hline Median & 6,508 & 7,16 \\
\hline Standard Deviation & 0,10200394 & 0,081525651 \\
\hline Minimum & 6,431 & 7,157 \\
\hline Maximum & 6,684 & 7,332 \\
\hline $\begin{array}{l}\text { Confidence } \\
\text { Level(95,0\%) }\end{array}$ & 0,002828038 & 0,002260281 \\
\hline
\end{tabular}


On the issuance date of Bond BNTT01B, the managers had no debt market timing ability since government bond benchmark rate is the closest to mean rate of its bootstrap window. BNTT01D another bond issuance done by PT Bank Pembangunan Daerah Nusa Tenggara Timur during 2009-2011. That bond was being issued at the date on which the government bond yield was closest to the maximum rate over its 5 working days bootstrap window. This bond issuance strengthens the inability of this company to do debt market timing.

Table 10. Descriptive Statistics for Each Bootstrap Window

\begin{tabular}{|l|r|r|r|}
\hline & BTPNO1ACN1 & BTPNO2A & BTPNO3A \\
\hline Mean & 6,6978882 & 8,6194128 & 6,991159 \\
\hline Standard Error & 0,000561562 & 0,001015362 & 0,000840923 \\
\hline Median & 6,705 & 8,629 & 6,998 \\
\hline Standard Deviation & 0,03970843 & 0,071796968 & 0,059462244 \\
\hline Minimum & 6,655 & 8,498 & 6,894 \\
\hline Maximum & 6,759 & 8,701 & 7,055 \\
\hline Confidence Level(95,0\%) & 0,001100908 & 0,001990556 & 0,001648578 \\
\hline
\end{tabular}

On issuing Bond BTPN01ACN1 and BTPN03A, PT Bank Tabungan Pensiunan Nasional Tbk had successfully chose the issuance date with the lowest rate over the 5 working days bootstrap window. The manager had perfect debt market timing ability in these bonds issuance. However, on the case of BTPN02A issuance, the managers are considered to have no ability to time its bond issuance since the actual government bond yield on corporate bond issuance date is closest to the mean rate of the bootstrap window.

Table 11. Descriptive Statistics for Each Bootstrap Window

\begin{tabular}{|l|r|r|}
\hline & FIFA01 C & FIFA11 C \\
\hline Mean & 8,2497132 & 7,0111294 \\
\hline Standard Error & 0,001682732 & 0,001231474 \\
\hline Median & 8,277 & 7,041 \\
\hline Standard Deviation & 0,118987104 & 0,08707833 \\
\hline Minimum & 8,068 & 6,877 \\
\hline Maximum & 8,401 & 7,119 \\
\hline Confidence Level $(95,0 \%)$ & 0,003298892 & 0,002414228 \\
\hline
\end{tabular}


The issuances of both Bond FIFA01C and FIFA11C were made on which the actual government bond yield on the issuance date were closest to the maximum rates of each 5 working days bootstrap window. Both bond issuances made by PT Federal International Finance during year 2009-2011 indicates that the company's manager had the worst ability to do debt market timing.

Table 12. Descriptive Statistics for Each Bootstrap Window

\begin{tabular}{|l|r|r|}
\hline & SMFP01CCN1 & SMFP03B \\
\hline Mean & 5,2822776 & 7,7228184 \\
\hline Standard Error & 0,000567158 & 0,001278738 \\
\hline Median & 5,265 & 7,704 \\
\hline Standard Deviation & 0,040104102 & 0,090420461 \\
\hline Minimum & 5,253 & 7,617 \\
\hline Maximum & 5,359 & 7,883 \\
\hline Confidence Level(95,0\%) & 0,001111878 & 0,002506888 \\
\hline
\end{tabular}

The analysis results for both Bond SMFP0CCN1 and SMFP03B are the same. These bonds were being issued at the dates on which the government bond benchmark rates were closest to the mean value of each 5 working days bootstrap window. Based on this condition, the managers of PT Sarana Multigriya Finansial are considered to have no ability in timing the company's bond issuance during year 2009-2011.

\section{Each Company's Market Timing Ability}

In order to reveal aggregate outcome and provide cross check, the analysis of each company's ability to time government bond benchmark rate on its whole issuance during 2009 until 2011 will be assessed. The process involves making average window of each company basis based on the number of bonds being issued by the company. Hence after, each company's ability to time government bond benchmark rates will be analyzed based on that single actual 5days window and the bootstrap data from that window. The 5 working days window resulted from averaging the total bonds issued by each company are presented on the below table: 
Table 13. Companies' Average Government Bond Rates on Actual 5Days Window (in \%)

\begin{tabular}{|c|c|c|c|c|c|c|}
\hline Number & $\begin{array}{c}\text { Company } \\
\text { Code }\end{array}$ & $\mathbf{T - 2}$ & $\mathbf{T}-\mathbf{1}$ & $\mathbf{T}$ & $\mathbf{T}+\mathbf{1}$ & $\mathbf{T}+\mathbf{2}$ \\
\hline \hline 1 & AMDF & 6,39 & 6,244 & $\mathbf{6 , 2 6 4}$ & 6,179 & 6,212 \\
\hline 2 & ASDF & 8,337 & 8,354 & $\mathbf{8 , 3 5 3}$ & 8,324 & 8,354 \\
\hline 3 & BCAF & 7,553 & 7,651 & $\mathbf{7 , 6 2 5}$ & 7,582 & 7,585 \\
\hline 4 & BEXI & 7,823 & 7,785 & $\mathbf{7 , 7 9 9}$ & 7,777 & 7,728 \\
\hline 5 & BJBR & 8,452 & 8,387 & $\mathbf{8 , 5 4 1}$ & 8,615 & 8,664 \\
\hline 6 & BNTT & 7,008 & 6,796 & $\mathbf{6 , 9 0 7}$ & 6,917 & 6,833 \\
\hline 7 & BTPN & 7,437 & 7,456 & $\mathbf{7 , 3 8 1}$ & 7,460 & 7,444 \\
\hline 8 & FIFA & 7,473 & 7,677 & $\mathbf{7 , 7 2 5}$ & 7,675 & 7,600 \\
\hline 9 & SMFP & 6,621 & 6,479 & $\mathbf{6 , 5 1 5}$ & 6,435 & 6,465 \\
\hline
\end{tabular}

The bootstrapped data are generated by resample the data in actual window 1000 times. The managers' capability from each company to do debt market timing will be analyzed by comparing the mean rate at $t$ with the value of distribution made by bootstrapping. The descriptive statistic for bootstrap data window after averaging total bonds issued by each company is summarized as follow:

Table 14. Descriptive Statistics for Each Company's Average Bootstrap Window

\begin{tabular}{|l|r|r|r|}
\hline & ADMF-Average & ASDF-Average & BCAF-Average \\
\hline Mean & 6,2593617 & 8,3441093 & 7,5990686 \\
\hline Standard Error & 0,001020591 & 0,000168711 & 0,000430647 \\
\hline Median & 6,24425 & 8,3525 & 7,595 \\
\hline Standard Deviation & 0,072166696 & 0,011929642 & 0,030451349 \\
\hline Minimum & 6,1785 & 8,324 & 7,552 \\
\hline Maximum & 6,3895 & 8,354 & 7,67 \\
\hline Confidence Level $(95,0 \%)$ & 0,002000806 & 0,000330747 & 0,000844257 \\
\hline
\end{tabular}

The average of 3-year maturity government bond benchmark rates at all three bonds' issuance date of PT Adira Dinamika Multi Finance (ADMF) is $6.264 \%$ (presented on Table 4.12). This rate is closest to the mean of its 5-days bootstrap window. The corporate bonds issuances by PT BCA Finance show identical outcome with PT Adira 
Dinamika Multi Finance in which the managers are deemed to have no ability to do debt market timing because they issued bonds at the time in which the government bond yield is the mean value of the 5 working days bootstrap window.

In the case of two bonds issuance by PT Astra Sedaya Finance (ASDF) from year 2009 to 2011, the average government bond yield at the issuance date $(8.353 \%)$ is closest to maximum rate in the bootstrap window $(8.354 \%)$. The managers of ASDF are considered to have the worst ability to time their bond issuances.

Table 15. Descriptive Statistics for Each Company's Average Bootstrap Window

\begin{tabular}{|l|r|r|r|}
\hline & BEXI-Average & BJBR-Average & BNTT-Average \\
\hline Mean & 7,78347708 & 8,5303133 & 6,889808 \\
\hline Standard Error & 0,000441084 & 0,001268601 & 0,001045398 \\
\hline Median & 7,7852 & 8,53 & 6,907 \\
\hline Standard Deviation & 0,031189358 & 0,089703633 & 0,073920789 \\
\hline Minimum & 7,7278 & 8,3295 & 6,7955 \\
\hline Maximum & 7,823 & 8,6635 & 7,008 \\
\hline Confidence Level(95,0\%) & 0,000864718 & 0,002487014 & 0,002049438 \\
\hline
\end{tabular}

The debt market condition on the bond issuances of PT Bank Ekspor Indonesia (BEXI), PT Bank Pembangunan Daerah Jawa Barat dan Banten (BJBR) and PT Bank Pembangunan Daerah Nusa Tenggara Timur are pretty much similar to what being concluded in the case of PT. Adira Dinamika Multi Finance and PT BCA Finance. The average government bond benchmark rates on the actual issuance dates (rt) are closest to the mean value of each boostrapped 5-working days window data. The managers had no ability to time their bond issuances at the date within their actual issuance date with the lowest government bond yield. 
Table 16. Descriptive Statistics for Each Company's Average Bootstrap Window

\begin{tabular}{|l|r|r|r|}
\hline & BTPN-Average & FIFA-Average & SMFP-Average \\
\hline Mean & 7,436153333 & 7,6280047 & 6,5033185 \\
\hline Standard Error & 0,000476563 & 0,001259051 & 0,000912567 \\
\hline Median & 7,436666667 & 7,6745 & 6,4785 \\
\hline Standard Deviation & 0,033698076 & 0,089028356 & 0,064528198 \\
\hline Minimum & 7,349 & 7,4725 & 6,435 \\
\hline Maximum & 7,505 & 7,725 & 6,621 \\
\hline Confidence Level(95,0\%) & 0,000934272 & 0,002468292 & 0,001789031 \\
\hline
\end{tabular}

PT Bank Tabungan Pensiunan Nasional Tbk (BTPN), who issued 3 bonds in total during 2009-2011 time period, is the only one company that successes to time its bond issuances at the date with the lowest government bond rates within the 5 working days window. The managers of PT Federal International are considered to have the worst capability to time its bond issuances, just like the case of PT Astra Sedaya Finance. They issued at the maximum government bond rates within the 5 working days bootstrap window.

The managers of PT Sarana Multigriya Finansial (SMFP) issued their bonds at the date that had the mean government bond yield over the 5 working days bootstrap window. This outcome classifies SMFP as the same category of those companies having no debt market timing ability.

\section{Overall Conclusion of Debt Market Timing Ability}

To test the debt market timing ability of all representative companies in this research, the average government bond benchmark rates only on the issuance date (average of $r_{t}$ from all bonds) will be compared to the value from total bootstrap window. The comparison will be done by conducting One Sample T-Test. Government bond yields at all corporate bonds issuance dates are presented in the below figure: 


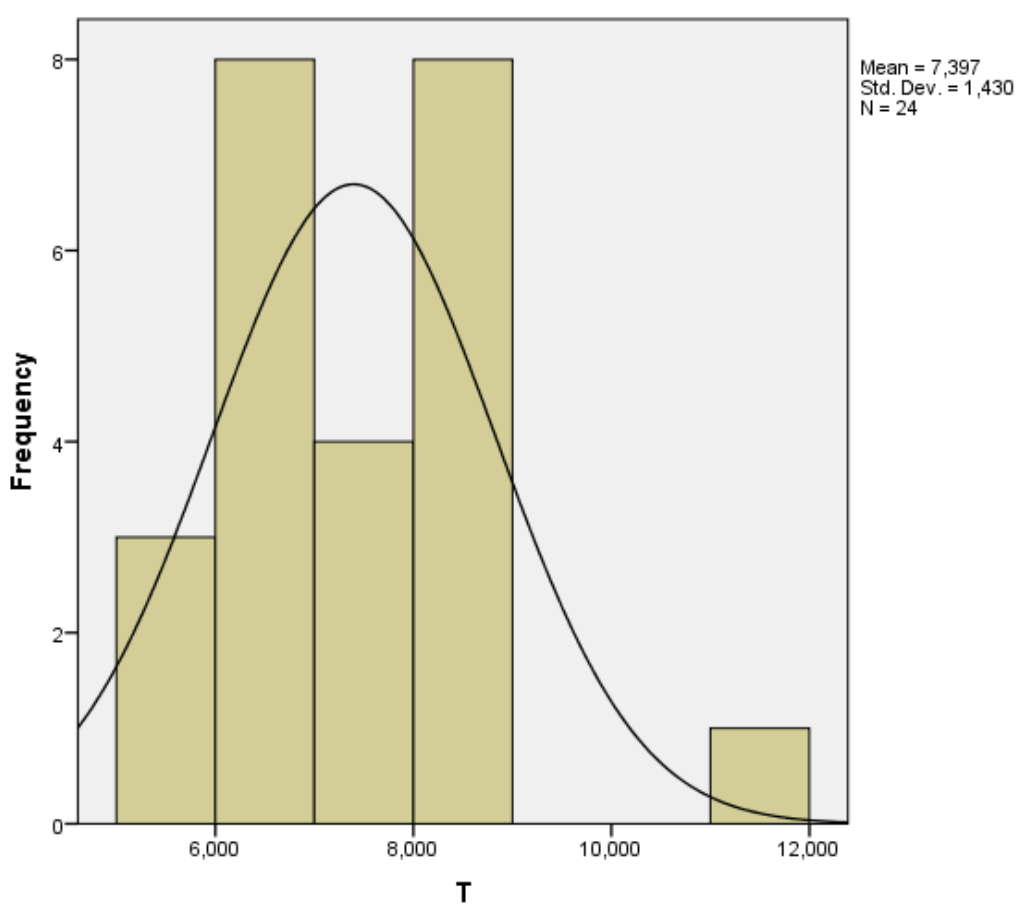

Figure 4. The distributions of government bond yields at time $t$

In conducting One Sample T-Test, the amount inputted in the box "test value" will be based on the three conditions, the amount of the $r_{\min }, r_{\text {mean }}$ and $r_{\max }$ from the total bootstrap window for all 24 bonds issuances presented in table 4.16. If the result of the first condition $\left(\mathrm{r}_{\min }\right)$ does not show significance level more than 0.05 , One Sample TTest using the second condition must be taken place. If the outcome from the first condition is significant, the null hypothesis one is not rejected and no need to test another condition.

Table 17. Descriptive Statistics for All Samples in Bootstrap Window

\begin{tabular}{|l|r|}
\hline & Overall Data \\
\hline Mean & 7,384976292 \\
\hline Standard Error & 0,003956359 \\
\hline Median & 7,138 \\
\hline Standard Deviation & 1,370522829 \\
\hline Minimum & 5,253 \\
\hline Maximum & 11,75 \\
\hline Confidence Level(95,0\%) & 0,007754399 \\
\hline
\end{tabular}


To test the first condition, the author conduct the One Sample T-Test by using the average of government bond rate as benchmark. The following 2 tables show the result presented from the test of first condition using One Sample T-Test:

Table 18. One-Sample Statistics for the first condition

\begin{tabular}{|l|r|r|r|r|}
\hline & $\mathrm{N}$ & Mean & Std. Deviation & Std. Error Mean \\
\hline $\mathrm{T}$ & 24 & 7,39692 & 1,430287 &, 291956 \\
\hline
\end{tabular}

Table 19. One-Sample Test for the first condition One-Sample Test

\begin{tabular}{|c|c|c|c|c|c|c|}
\hline & \multicolumn{6}{|c|}{ Test Value $=5.253$} \\
\hline & \multirow[t]{2}{*}{$t$} & \multirow[t]{2}{*}{ df } & \multirow[t]{2}{*}{ Sig. (2-tailed) } & \multirow[t]{2}{*}{$\begin{array}{c}\text { Mean } \\
\text { Difference }\end{array}$} & \multicolumn{2}{|c|}{$\begin{array}{l}\text { 95\% Confidence Interval of the } \\
\text { Difference }\end{array}$} \\
\hline & & & & & Lower & Upper \\
\hline $\mathrm{T}$ & 7,343 & 23 &, 000 & 2,143917 & 1,53996 & 2,74787 \\
\hline
\end{tabular}

The result of the first condition does not show significance level above 0.05 . The average of government bond benchmark rates on actual issuance dates (average of $\mathrm{rt}$ ) over the whole sample (24 corporate bonds) is $7.397 \%$. After comparing this value to the minimum value of the bootstrap window, $5.253 \%$, the outcome shows significance level that is only 0.000 .

Based on the t-test procedure, the first condition's null hypothesis will be rejected if $\mathrm{t}<-2.069$ or the $\mathrm{t}>2.069$. This value, 2.069 is obtained by looking at the t-distribution table with $\alpha=0.05$ and $\mathrm{df}=23$ (total samples minus 1). The $t$ value represented by the test or manually calculated by t-statistic formula resulted in the number of 7.343.

$$
\begin{gathered}
t=\frac{7.39692-5.255}{1.430287 / \sqrt{24}} \\
t=7.343295
\end{gathered}
$$

As the result does not satisfy the first condition, another One Sample T-Test must be taken place using the second condition. The second condition is analyzed using One Sample T-Test by inputting the mean 
value of bootstrap 5-days window (7.385) to the box "test value" instead of 5.253. The outcomes of the second condition are as follow:

Table 20. One-Sample Statistics for the second condition One-Sample Statistics

\begin{tabular}{|l|r|r|r|r|}
\hline & $\mathrm{N}$ & Mean & Std. Deviation & Std. Error Mean \\
\hline $\mathrm{T}$ & 24 & 7,39692 & 1,430287 &, 291956 \\
\hline
\end{tabular}

Table 21. One-Sample Test for the second condition

\begin{tabular}{|c|c|c|c|c|c|c|}
\hline \multicolumn{7}{|c|}{ One-Sample Test } \\
\hline & \multicolumn{6}{|c|}{ Test Value $=7.385$} \\
\hline & \multirow[t]{2}{*}{$\mathrm{t}$} & \multirow[t]{2}{*}{ df } & \multirow[t]{2}{*}{ Sig. (2-tailed) } & \multirow[t]{2}{*}{$\begin{array}{l}\text { Mean } \\
\text { Difference }\end{array}$} & \multicolumn{2}{|c|}{$\begin{array}{c}95 \% \text { Confidence Interval of the } \\
\text { Difference }\end{array}$} \\
\hline & & & & & Lower & Upper \\
\hline$T$ &, 041 & 23 & 968 & 011917 &,- 59204 & 61587 \\
\hline
\end{tabular}

The average of government bond benchmark rates on actual issuance dates ( $\mathrm{r}$ only at $\mathrm{t}$ ) over the whole sample (24 corporate bonds) is $7.397 \%$. Whereas, the mean rate from the total bootstrap data of overall windows is $7.385 \%$. Through One Sample T-Test, this comparison generates a significance level of 0.968 .

From t-distribution table, it can be concluded that the critical value is 2.069 ( $\mathrm{df}=23$ and $\alpha=0.05$ ). The second condition null hypothesis will be rejected if $\mathrm{t}$ is more than 2.069 or $\mathrm{t}$ less than -2.069 . The $\mathrm{t}$ value calculated from $t$ statistic formula or by the test from SPSS for this second condition result in the amount of 0.041 .

$$
\begin{gathered}
t=\frac{7.39692-7.385}{1.430287 / \sqrt{24}} \\
t=0.040828
\end{gathered}
$$

Since the result shows t-value that is not more than 2.069 and the test's significance level is more than 0.05 , and hence the null hypothesis of the second hypothesis is not rejected. This condition defines that overall the representative companies were not having the ability to time the debt issuance on which the government bond benchmark rate is the lowest from the 5-days window. They have the ability to issue bond on which the debt market condition (represented 
by the government bond benchmark rates) is the average from the 5 working days windows within the actual issuance date.

\section{One Sample T-Test}

In order to investigate the validity of the findings, One Sample T-Test for all samples will be implemented. The $95 \%$ confidence interval is set as the benchmark to analyze the mean difference. If the outcome from test shows that they are statistically different from each other (significant level is less than 0.05), therefore the data analysis of this research is not valid. Additionally, if that happens, it means that Bootstrap could not and should not be utilized to investigate the debt market timing ability to prevent deviate result.

To test the mean difference, SPSS uses the input data of all samples interest rate in actual window to compare it with the amount 'that the author will directly input 7.385 (based on mean value in Table 4.16) in the box "test value" provided in One Sample T-Test of SPSS application. The followings are the result presented from One Sample T-Test on SPSS:

Table 22. One-Sample Statistics One-Sample Statistics

\begin{tabular}{|l|r|r|r|r|}
\hline & \multicolumn{1}{|c|}{$\mathrm{N}$} & Mean & Std. Deviation & Std. Error Mean \\
\hline Rates & 120 & 7,38537 & 1,376300 &, 125638 \\
\hline
\end{tabular}

Table 23. One-Sample Test

\begin{tabular}{|c|c|c|c|c|c|c|}
\hline \multicolumn{7}{|c|}{ One-Sample Test } \\
\hline & \multicolumn{6}{|c|}{ Test Value $=7.385$} \\
\hline & \multirow[t]{2}{*}{$\mathrm{t}$} & \multirow[t]{2}{*}{ df } & \multirow[t]{2}{*}{ Sig. (2-tailed) } & \multirow[t]{2}{*}{$\begin{array}{c}\text { Mean } \\
\text { Difference }\end{array}$} & \multicolumn{2}{|c|}{$\begin{array}{l}95 \% \text { Confidence Interval of the } \\
\text { Difference }\end{array}$} \\
\hline & & & & & Lower & Upper \\
\hline Rates &, 003 & 119 & .998 & .000367 & -.24841 & .24914 \\
\hline
\end{tabular}

As seen from the above table, the average from the actual window of the total corporate bonds is $7.38537 \%$. Based on One Sample T-Test, this value is not statistically different from that resulted through bootstrap, which is 7.385 , that was previously inputted to the 'test value' box. The result shows an extremely high significance level, 0.998 . 
Based on t-test, the mean from actual window will be said to be statistically different from bootstrap window if the t-value generated from formula or test is less than -1.98 or more than 1.98 . The 1.98 is the critical value obtained from the t-distribution table with $\mathrm{df}=120$ and $\alpha=0.05$. For better conclusion, the cross-check of SPSS test is done by calculating the $\mathrm{t}$-value from $\mathrm{t}$ statistic formula. The $\mathrm{t}$-value is:

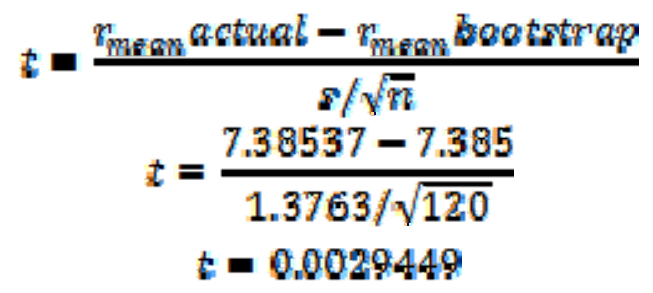

This calculated t-value is not more than 1.98. Together with significance level that is more than 0.05 , they provide proofs that the mean of actual data is not statistically different from the bootstrap data. It indicates that bootstrap can be used as a tool to analyze the debt market timing ability.

Additionally, the standard error represented from actual window $(0.125638)$ is statistically higher than that on the bootstrap window ( 0.003956359 on Table 4.16). From this fact, it can be concluded that bootstrap provides more robust tool and standard to analyze the debt market timing ability since it allows the construction of confidence interval. Hence after, the choice to compare the actual government bond rates on time $t$ to the bootstrap window value instead of to the actual window is a wise selection because it provides more accurate data findings.

\section{CONCLUSION}

Bond is becoming popular in Indonesian capital market as there is an ongoing decline in interest rates and also ongoing increase in the credit rating of Indonesian bond. Both conditions are beneficial for the sake of bond issuers to be able to issue bonds at a low cost. Additionally, the great credit rating increases investors' confidence in entrusting their money in bond instruments. This great condition should be utilized by companies that have habits in issuing bonds by 
having the ability to determine the right time to issue bonds in which the cost of this kind of financing is relatively low.

This paper focus on investigating the ability of representative companies to time the government bond benchmark rates within their actual issuance of 3-year and 7 year maturity corporate bond during 2009-2011. The conclusions for this research are as follows:

a. As per bond basis, the result shows that 12 bonds being issued at the date on which the government bond yield is the mean from the 5 working days bootstrap window. This condition indicates that the companies' managers involved in those 12 bond issuances had no market timing ability. On the other hand, six corporate bonds were successfully being issued on the date that had the minimum government bond rate within the 5 working days bootstrap window (The managers had perfect ability to time these issuances). However, another six corporate bonds were being issued at the date on which the government bond yield is the maximum of the bootstrap window. In another word, the companies had the worst ability to time these 6 bond issuances.

b. The analysis of each company basis reveals that 6 companies had no ability to time their bonds issuances, 2 companies had the worst ability to do debt market timing, while only 1 company had the perfect ability to time its bond issuance. Surprisingly, companies who issued bonds more frequently than others do not represent the superior ability in doing debt market timing. PT Bank Ekspor Indonesia and PT Adira Dinamika Multi Finance that issued more than the others (issued 5 and 4 bonds consecutively) are those in the category of having no debt market timing ability, while the only 1 company that had perfect debt market timing ability is PT Bank Tabungan Pensiunan Nasional Tbk that issued 3 bonds. Even so, the two companies that had worst ability to time their bond issuances are those with only 2 bond issuances during the period (Those in the category of companies with the least number of bond issuances).

c. As in the case of overall data capabilities to time their bond issuances, the result from One Sample T-Test does not reject the second condition null hypothesis. This condition exhibits the exposure of representative companies' inability to determine the right time to issue bond. Overall, Indonesian publicly listed companies issued bonds at the date on which the government bond 
yield is the mean value from the 5 working days bootstrap window.

d. The representative companies of this paper, those who issued bonds more frequently than other companies and hence should be those having the capability to do debt market timing, fail to issue bonds on the date on which the government bond yield is the minimum within the 5 working days window of their actual bond issuances.

\section{Limitations}

\section{a. Time constraint}

Due to the limited time, the debt market timing ability is only observed in the 5-working days window. The one-month window and one-quarter window that are tested by Frank and Nezafat in United States are not tested in this paper and hence the result only represents the one-week window outcome in Indonesian context.

\section{b. Sample size}

The sample of this research is limited to issuance of three-year and seven-year maturity bonds by the selected representative companies during year 2009 until 2011. Further research can either extend the period of time being investigated or increase the sample size.

c. Unavailability of CDS price per company

Contradict to United States that has Credit Default Swaps price per company, Indonesian's information regarding CDS price is limited only to the country basis. There is no CDS prices reported on the basis of company available in Indonesia.

Thereafter, this research is limited to only one variable that affect the debt market, the risk free rate. If only Indonesia has extensive information regarding CDS price, this research can add CDS price as one additional variable to test Indonesian public listed companies' ability to time debt issuances.

\section{REFERENCES}

Alti, A., 2003, How Persistent Is the Impact of Market Timing on Capital Structure, Working Paper from University of Texas Austin, pp. 1-35 
Asian Development Bank (ADB) Team, 2011, ASEAN+3 Bond Market Guide: Section 3: Indonesia Bond Market Guide. Jakarta.

Baker, M. and R. Wurgler, 2002, Market Timing and Capital Structure, Journal of Finance 57, pp. 1-32.

Bodie, Z., Kane, A., Marcus, A.J., 2011, Investments and Portfolio Management (Global Edition). New York. McGraw-Hill Companies, Inc.

Bougatef, K., Chichti, J., 2010, Equity Market Timing and Capital Structure: Evidence from Tunisia and France, International Journal of Business and Management, 5(10), 167-177

Çelik, S., and Akarim, Y. D., 2013, Does Market Timing Drive Capital Structure? Empirical Evidence from an Emerging Market. International Journal of Economics and Financial Issues, 3(1), 140-n/a. Retrieved from http://search.proquest.com/docview/1266465912 accountid=3 1532

Comer, G., Boney, V., and Kelly, L., 2012, High Quality Bond Funds: Market Timing Ability and Performance, Rochester, Rochester: doi: http://dx.doi.org/10.2139/ssrn.680681

Cooper, D. R, Schindler, P. S., 2001, Business Research Methods (7th ed). New York, United States: McGraw-Hill.

De Bie, T., \& De Haan, L., 2007, Market Timing and Capital Structure: Evidence for Dutch Firms. De Economist, 155(2), 183-183. doi: http://dx.doi.org/10.1007/s10645-007-9054-1

Efron, Bradley, and Robert J. Tibishirani, 1993, An Introduction to the Bootstrap, New York: Chapman \& Hall/CRC.

Frank, M. Z., and Nezafat, P., 2010, Credit Market Timing, Rochester, Rochester: doi: http://dx.doi.org/10.2139/ssrn.1571798

Graham, J. R., and C. R. Harvey, 2001, The Theory and Practice of Corporate Finance: Evidence from the Field, Journal of Financial Economics 60, pp. 187-243.

Huang, R. and J.R. Ritter, 2005, Testing the Market Timing of Capital Structure. Working Paper from University of Florida, pp. 1-44. 
Hovakimian, A., T. Opler and S. Titman, 2001, 'The Debt-Equity Choice', Journal of Financial and Quantitative Analysis, 36, pp. 1-24.

Ibrahim, H, 2008, Pengaruh Tingkat Suku Bunga, Peringkat Obligasi, Ukuran Perusahaan dan DER Terhadap Yield To Maturity Obligasi Korporasi Di Bursa Efek Indonesia Periode Tahun 2004-2006. Retrieved from http://eprints.undip.ac.id/17480/1/Hadiasman_Ibrahim.pdf

Indonomics, 2012, A Positive Outlook for Indonesia's Corporate Bonds. Retrieved from http://indonomics.com/?p=93

Kayhan, A., and S. Titman, 2005, Firms' Histories and Their Capital Structure. NBER Working Paper, pp. 1- 51.

Keller, G., 2005, Statistics for Management and Economics (Seventh ed.). Duxbury. Thomson Brooks/Cole.

Leary, M.T., and M.R. Robert, 2005, Do Firms Rebalance Their Capital Structure?, Journal of Finance, Vol. 60 No. 6, pp. 2575-2619.

Lemmon, M. L., M. R. Robert, and J. F. Zender., 2005, Back to the Beginning: Persistence and the Cross-Section of Corporate Capital Structure, Working paper from University of Colorado, pp. 1-40.

Levin, R.I., and Rubin, D.S., 1998, Statistics for Management (Seventh ed.). New Jersey. Prentice-Hall, Inc.

Levine, D. M., Stephan, D. F., Krehbiel, T. C., and Berenson, M. L., 2008, Statistics for Managers Using Microsoft Excel (5th edition), New Jersey, Pearson Education International.

Manurung, N., and Moestafa, B., 2012, Indonesia Regains Investment Grade at Moody's After 14 Years. Retrieved from http://www.bloomberg.com/news/2012-01-18/indonesiasovereign-debt-rating-is-raised-to-investment-grade-bymoody-s.html

McClave, J. T., and Sincich, T., 2006, Statistics (Tenth edition), New Jersey, Pearson Education, Inc. 
Modigliani, F., and Miller, M., 1958, The Cost of Capital, Corporation Finance and the Theory of Investment, The American Economic Review, 68(3), 261-297 (June).

Myers, S.C., and N. Majluf., 1984, 'Corporate Financing and Investment Decisions When Firms Have Information that Investors Do not Have,' Journal of Financial Economics, 13, pp. 187-221.

SAS Institute Inc., 2009, SAS/STAT 9.2 User's Guide the TTEST Procedure (Book Excerpt), Retrieved from http://support.sas.com/documentation/cdl/en/statugttest/61844/ $\mathrm{PDF} /$ default/statugttest.pdf

Sekaran, U., \& Bougie, R., 2009, Research Methods for Business: A Skill Building Approach. Chichester, West Sussex, United Kingdom: John Wiley \& Sons Ltd.

Setyawan, I. R., 2012, Empirical Tests for Market Timing Theory of Capital Structure on the Indonesian Stock Exchange, Rochester, Rochester: doi: http://dx.doi.org/10.2139/ssrn.1980014.

Welsch, I., 2004, Capital Structure and Stock Return, Journal of Political Economy Vol. 112, pp. 106-131.

Zar, J., 1999, Biostatistical Analysis (4th ed.), Upper Saddle River, NJ, Prentice Hall. 